\title{
Legal Responses in the Area of Migration Security after 2015 Migration Crisis in Italy, Germany and Poland. Whose Security Does National Law Protect: Migrants or Citizens?
}

\author{
Anna Magdalena Kosińska \\ Department of International and European Union Law, John Paul II Catholic University of Lublin, Lublin, Poland
}

Corresponding author: anna.kosinska@kul.pl; Tel.:+48 505035927

Submitted: 14 November 2020 | In revised form: 12 May 2021 | Accepted: 18 August 2021 |

Published: 7 October 2021

\begin{abstract}
The aim of the article is to analyze the changes introduced recently (2018-2019) in the national migration law of the selected Member States: Italy, Poland and Germany and to examine whether there exist guarantees of the right to migration security and guarantees for the realization of the principle of migration security priority at the level of national legislation. The second problem under investigation concerns the fact whether the changes introduced in the legislation recently ensure a higher level of migration security in comparison with the previous regulations. Finally, the analysis carried out in the current article is intended to demonstrate whether national law protects the rights of migrants and the receiving society in equal measure or whether certain fundamental rights which migrants are entitled to are at risk of being derogated due to the necessity of providing security to migration processes and the protection of the receiving society. The paper analyzes in detail the legislative initiatives and amendments introduced in migration and refugee law in Germany, Italy and Poland. What is more, the author gathers and analyzes the most representative national case law concerning the asylum and return migration.
\end{abstract}

Keywords: asylum law; migration crisis; return migration; right to migration security; security of migration

\section{Introductory Remarks}

The present article is an effect of the last stage of the research conducted within the framework of a broader project entitled "Security Management in European Asylum and Return Law and Policy with Regard to the Migration Crisis" [1]. Under the existing research program, it was demonstrated that in the law and policies of the European Union there exists the so-called principle of migration security priority, "in accordance with which it is necessary to guarantee the highest level of security to all the actors of the migration process, that is to both migrants themselves, as well as the receiving society. This should occur both at the level of legislation and at the level of the application of the law" [2]. Further, for the purposes of the conducted research, the so-called right to migration security has been defined as the third-generation law, guaranteed under the provisions of EU primary law ([3], Art. 67,77-79), which protects all the participants of migration processes-both the very migrants, as well as the receiving society.

However, it seems that even a broader analysis of the union's acquis (including the case law of the Court of Justice of the EU) is not sufficient to determine the level of the guaranteed migration security in the area of the European Union. It is the result of at least two factors. Firstly, the space of the so-called Area of Freedom, Security and Justice constitutes 
a competence shared between the EU and the Member States ([3], Art. 4(2)(j)). Therefore, the Member States may introduce legislation in the area of return law and for granting international protection "only to the extent that the Union has not done so" ([4], p. 117). Such a regulation of competence allows for a certain, albeit limited, freedom in the creation of unique migration policies-there might be some individual differences between different Member States in the regulations concerning the areas which are not unified within the framework of Union's law. Apart from that, it should also be remembered that the existing acts of secondary law in the area of returns and granting of international protection are nevertheless directives which require implementation, leaving the Member States freedom in the choice of form and methods. The directives are binding with regard to the aims that they specify and the time frame for their implementation ([3], Art. 288).

Secondly, the full analysis of the processes of managing migration in the European Union is necessary to resort to the term Multi Level Governance (MLG), in accordance with which, the Member States do not play a dominant role in the creation of Union's policies, but rather, the processes of managing the Union occur simultaneously at the national, supranational and subnational levels in a parallel way ([5], p. 39). As S. Prince observes, the MLG doctrine consists in a mode of governance of "interconnected arenas" in which local, regional, national and supranational levels of government depend upon each other" ([5] p. 40). In the same vein, the management of migration security concerns both the international and national levels, as well as to a large degree the regional level ([6], p. 6).

The migration crisis turned out to be a considerable challenge for Member States, which did not expect such a huge influx of migrants in 2015. In accordance with the data of the European Asylum Support Office, it is estimated that 1 392155 applications for international protection were then submitted in the EU ([7], p. 5). As a result, Member States were forced to change the priorities of their migration policies in accordance with the political instruments adopted by the EU. Those instruments included, among others, the Communication from the European Commission "European Agenda on Migration" [8]. Two types of narration emerged in the political discourse at that time: one that called for strengthening the need for solidarity-based actions among Member States with a view to effective migration management ([9], pp. 80-94), and another, a conservative narration, pointing out to potential threats related to increased migration movements (an example of transferring the latter into real actions was, among others, the reintroduction of controls at internal borders ([10], p. 39). Taking into account the fact that migration policy, in accordance with Art. 4 of the Treaty on the Functioning of the European Union, is a competence shared between the Union and the Member States, an analysis of the legislation on migration adopted at the national level, as well as the case law of national courts, will allow for an assessment as to which actions became a priority for the Member States.
Taking into account the fact that migration policy, in accordance with Art. 4 of the Treaty on the Functioning of the European Union, is a competence shared between the Union and the Member States, an analysis of the legislation on migration adopted at the national level, as well as the case law of national courts, will allow for an assessment as to which actions became a priority for the Member States.

\section{Research Objectives of the Article}

\subsection{Research Thesis}

The right to migration security is guaranteed in the primary law of the EU, which has been demonstrated in the previous stage of the research [11]. Therefore, if Member States are bound by the treaties, which is beyond doubt, consequently they are also obliged to realize the guarantees of the right to migration security at the level of the currently pursued migration policy and the existing legislation in this area.

The aim of the article is to analyze the changes introduced recently (2018-2019) in the national migration law of the selected Member States: Italy, Poland and Germany and to examine whether there exist guarantees of the right to migration security and guarantees for the realization of the principle of migration security priority at the level of national legislation. The second problem under investigation concerns the fact whether the changes introduced in the legislation recently ensure a higher level of migration security in comparison with the previous regulations. Finally, the analysis carried out in the current article is intended to demonstrate whether national law protects the rights of migrants and the receiving society in equal measure or whether certain fundamental rights which migrants are entitled to are at risk of being derogated due to the necessity of providing security to migration processes and the protection of the receiving society.

\subsection{Legal Axiological Paradigm of Migration Security}

In the course of the conducted analysis, what proved especially useful was reference to the model of an ideal system of national law, devised for the purpose of the current article, which would fully guarantee the realization of the migration security priority and the right to migration security.

It is beyond doubt that the migration crisis is a phenomenon which results in the actions undertaken by the states with a view to safeguarding and protecting sovereignty, citizenship, national security and identity ([12], p. 347), which leads to the so-called securitization of migration ([12] pp. 352-353, [13] p. 21). As a consequence, migration law becomes "crimmigration"-a set of norms which are to large degree administrative, but with the possibility of applying criminal sanctions ([14], pp. 293-295). The very process of managing the crisis leads to animated discussions centered on the values building the migration system. Hence, the doctrine faces the questions to the effect whether the states have the right to exclude migrants from 
social life or whether perhaps it is necessary to reimagine citizenship and guarantee each third-country national the right to association with the host society ([15], pp. 152-312). Further doubts are raised by the issue of the regulation of migrant flows through the territory of the receiving states and concerns over guaranteeing migrants the right to full mobility ([16], p. 11-16). To my view, an ideal system of national law should be based on the balancing of the interests of the receiving society and those of the groups of migrants, as well as the rights of individual representatives of those groups. What is more, it should be ensured that the above receive equal protection due to the inherent and inalienable dignity of each human being. A system of migration law such as this should be constructed on the following values:

- firstly, in a democratic society, it is precisely the citizens that should have the right to decide on the scope of migration policies realized by the state (right to self-determination), even though it is beyond doubt that this right should be exercised in accordance with such values as human rights dialogue ([17], p. 254), fairness towards migrants and building the integrated society ([18], pp. 153-156);

- protection of migrants' rights should be understood as a specific basis for the creation of migration law by the Member States due to the fact that, as P. De Bruycker observes, "the EU has developed a real philosophy of migration that respects the human being behind every migrant" ([19], p. 148);

- thirdly, an important axiological term which might serve as a guideline for the creation of policies and national migration legislation is the concept of solidarity (co-called normative solidarity) ([19], p. 151) and commonality (in accordance with the triad proposed by P. De Bruycker: common legislation-common objectives-common implementation) ([19], p. 152, [20]). The migration law of the Member States impacts the management of the migration flows in the whole of the European Union and should respect the needs of the whole of the Union as a community, whereas the national legal system, together with the norms of the public international migration law and the European Union's law form a system of communicating vessels, intertwined with one another. Without questioning the mutual interaction of those legal orders, it is worth proposing that national law also be constructed in the spirit of solidarism within pluralism, which entails the betterment of the international order, together with respect for the rights of an individual and human security ([21], pp. 76-77);

- fourth, an indispensable element of the effective national law migration system is to have the rightful ([22], p. 77) and fair integration processes regulated in the legislation, with no right to exclusion as a rule (only as an exception), proceeded due to the living together principle [23-25].

The above concept is also connected with the one of social membership, that is participation in the receiving society, despite the lack of legal legitimacy ([26], p. 150, [27], p. 244), which concerns, to a large degree, irregular migrants working in the grey area. In my opinion, the law of the Member States should facilitate the legalization of the stay of the active members of society, when they do not pose a threat to order and public security. Such a process in effect is of benefit to all.

All in all, it seems inevitable that modern EU states will be experiencing immigration at increasing levels. Therefore, adjusting legal norms to the needs resulting from the dynamics of social phenomena ([28], p. 23) will be indeed necessary. Such a process entails a meandering art of reaching difficult compromises, requiring the application of the principle of the golden mean in order to achieve the right balance between the values in need of protection-the rights of migrants and those of the receiving society, the two of which do not necessarily have to mean one and the same thing. The above also entails the ability to dynamically interpret the law by the agencies responsible for its enforcement, which will facilitate an appropriate granting of protection to the group which requires assistance in the given situation.

\section{An Analysis of Legal Changes in the Post-crisis Period}

\subsection{Methodology}

The present analysis concentrates on the changes in legislation and the application of law in the three selected Member States, that is in Italy (which has experienced one of the greatest migration pressures since 2015) and Germany (which received a significant number of persons seeking protection during the escalation of the migration crisis). With the two above belonging to the so-called "old Member States", the third selected state that comes under scrutiny is Poland, a relatively new Member State (located outside the main migration routes). Such a selection of legislative solutions from geographically varied locations provides ample opportunity for illustrating an array of divergent experiences and needs at the level of creation and application of migration law. Despite the fact that the selected Member States are obligated to implement EU law to the same extent, they are faced with entirely different challenges regarding migration. The present article is in fact complementary to the existing considerations by the same author with regard to the implementation of the right to migration security and expands them with an analysis of the situation in the selected Member States, the illustration of the process of implementation of EU law into national legal systems and the extent to which national legislators follow the principles of the migration policy of the EU.

In order to answer the proposed research thesis, two categories of sources have been subject to analysis. Firstly, they are the sources of law-primarily the acts adopted in the years 2018-2019 in the selected Member States. The decision to focus on this period of time was also by no 
means accidental. It seems that taking into account the length of the legislation process, the acts adopted in 2018 and 2019, that is almost three years after the escalation of the migration crisis, are to constitute long-term solutions for the challenges faced by the Member States, and they are not merely interim measures. The fact that a certain period of time has elapsed since the beginning of the escalation of the crisis also allows for a certain perspective and reflection, as well as a greater objectivity in the adopted measures. Secondly, the analysis centers on the practical application of the laws by the state administration authorities and the current jurisprudence of national courts. Due to the broad scope of the subject under examination, the article is also intended to instigate further discussion.

As for the methodology for deciding on the case law of the Member States, for obvious reasons the author had to be selective and make a choice. The analysis of the selected rulings was based on a qualitative, not quantitative approach. The author assumed that due to a certain delay in the actions of national legislators, it was the case law that provided a specific barometer for the necessary actions in the area of migration management. Simultaneously, case law offers an explicit overview of the problems faced on a daily basis by both migrants and administrative bodies responsible for their management. In the choice of the case law, it was crucial whether the doctrine, as well as various NGOs, took interest in them. The NGOs had to have experience in advancing the rights of refugees, asylum seekers, and displaced person, as well as be recognizable in Europe, (ECRE-European Council on Refugees and Exiles, PICUM-Platform for International Cooperation on Undocumented Migrants). Further, the case law had to fall within the concern of national and European bodies responsible for the protection of human rights (European Union Agency for Fundamental Rights, Office of the Ombudsman).

In the analysis of the collected material, the applied methods were typical of legal sciences, such as linguistic, systemic, purposive and comparative interpretation. Apart from that, due to the dynamics in the shaping of migration processes and their variety, for the purpose of analyzing the sources of law and the case law, the hermeneutical method was used, in accordance with which law is a cultural construct, being constantly in the process of constituting itself in the course of social communication ([29], p. 121).

The article discusses the legal situation as of 1.12.2020.

\subsection{National Law of the Member States}

\subsubsection{Italian legislation in the post-crisis period}

The Italian Republic introduced broad amendments in their legal system in the years 2018-2019 in response to the influx of migrants. Due to the limited scope of the present analysis, only the most important of the legal changes in the area of asylum and return policy will be presented.

The first significant and the most controversial change in the law that should be mentioned is the so-called "Decreto Salvini" [30], that is a legal act reforming the Italian asylum system. It was amended after a few months with the famous Decree 132/2018 [31].

The Decree is an instrument of the realization of Italy's restrictive policy on migration and the content of the legal act was written by Matteo Salvini, the leader of "Lega Nord" since 2013, a party known for its anti-immigration outlook ("Stop Immigrazione") and actions aimed at removing irregular migrants from the territory of Italy [32].

In the justification, at the beginning of the decree, it might be read that the aim of the legal changes is to be able to predict in advance the necessary resources allowing for individualized granting of residence permits on humanitarian grounds, as well as the strengthening of the protection of public security [33].

As a result, the granting of permissions on humanitarian grounds (humanitarian protection) became practically impossible after the new legislation had been implemented $[34,35]$. Other forms of residence permits were maintained in Italy, but with limited resources and addressed at a limited circle of beneficiaries [36-38]. It is worth emphasizing that a permit to stay for humanitarian reasons allowed for the regularization of the residence of a foreign national, who did qualify for international or subsidiary protection, but whose return to the country of origin would have a high risk of inhuman treatment [39].

In the discussion on the subject of the appropriateness of the reform, the constitutionality of the introduced changes $[40,41]$ was also contested, also with regard to the adopted form of the decree, which may become legally binding only in the situation of emergency (in accordance with the systematics of Italian sources of law, decreto legislative is the so-called fonti primarie, but in the hierarchy of the sources of law they are located below legge, that is acts. As Cecilia Corsi argues, it was by no means justifiable to talk about the state of emergency in the year 2018. What is more, the general number of migrants arriving to Italy decreased significantly in comparison with 2016 and 2017. Corsi also points out to the extremely important issue of the correlation between national law and the norms of international law (in this case the Common European Asylum System) and the necessity to ensure compliance with the above, in accordance with Art. 10 of the Italian Constitution [42]. In the system of the Geneva Convention, the stay for humanitarian reasons allows for the protection against refoulement of persons being in a special situation, that is stateless persons, or persons who committed various criminal acts and are excluded from international protection [43]. However, it should be remembered that protection against refoulement is absolute in nature and the obligation of the Member States to observe it was confirmed by international courts on numerous occasions $[44,45]$.

What is also surprising is that the reform initiated by Decreto Salvini revokes the changes adopted several years ago, both in the area of detention [46-48], as well as reception. In accordance with the changes introduced in 2018, persons seeking international protection are not allowed to stay in the so-called SPRAR centers (Sistema di pro- 
tezione richedenti asilo e rifiugiati, created under the legge 189/2002 [49]). They are available only to the beneficiaries of international protection and unaccompanied minors ([50], p. 15). Persons undergoing the refugee procedure are directed to the so-called C.A.S.-Centri do accoglienza straordinaria, which do not provide such high reception standards as SPRAR.

Another significant legal amendment for the evaluation of migration security was adopted in 2019. This is legge $53 / 2019$ of June 2019 concerning specific regulations in the area of public order and security [51], replaced further by legge 77/2019 (the so-called decreto sicurezza bis) [52]. In accordance with the reasoning, the legge was adopted on account of the extraordinary need for strengthening the instruments against irregular migration.

In accordance with Art. 1 legge-decreto entitled: the means of protecting public order and public security in the area of migration, the Minister for the Internal Affairs has the right, with respect to the international obligations of the Italian Republic, to limit or reduce transit, arrival or stoppage of vessels on territorial waters, in case if there exists a risk to public order and public security with regard to the entry of such vessels onto the territorial waters. The adopted law aroused considerable controversy, especially regarding its compliance with international law binding for Italy. Some concerns were voiced here, among others, by the ASGI (Associazione per gli Studi Giuridici sull'Immigrazione), pointing out that the adoption of a prohibition of entry into ports or onto territorial waters might be contrary to the obligation to save persons in a situation of distress, which is binding obligation under Art. 98 of the convention of Montego Bay [53].

In a parallel way to the above amendments, a decree of the Minister of Foreign Affairs, determining the list of the safe countries of origin [54] was issued. In accordance with the list, the Italian Republic deemed the following countries as safe: Albania, Algeria, Bosnia and Herzegovina, Republic of Cabo Verde, Ghana, Kosovo, North Macedonia, Morocco, Montenegro, Senegal, Serbia, Tunisia and Ukraine. The list met with protests from non-governmental organisations, which argued that the so-called vulnerable applicants should be excluded from the list and their applications should be examined in accordance with general norms [55].

\subsubsection{Legislation changes in Germany in the post-crisis period}

Moving further, also the Federal Republic of Germany decided to introduce changes in their migration law. In total, the amendments adopted in 2019 included 8 legal acts [56]. It is worth pointing out that during the migration crisis, the government of Angela Merkel declared that Germany would receive all the persons in need of international protection, acknowledging thus the priority of solidarity within the EU migration policies [57]. As a result of the said declaration, 1 091894 applications for international protection were submitted in the Federal Republic of Germany in 2015 [58], whereas national bodies became responsible for both examining the applications, as well as ensuring that the persons concerned have access to social welfare, and in the case of decisions refusing protection, that they are returned to their country of origin. Among the most important new legislation one should mention the so-called "orderly return act". In accordance with the Communication issued by the Minister for the Internal Affairs on August 21, 2019: "The law mainly concerns persons whose applications for asylum were rejected and in the case of whom, after an extensive legal procedure, it was established that they are not in need of protection under any scope and that they must leave the territory of the Federal Republic. The law implements the agreement of the governing parties in the coalition agreement and the preparation of the project for the general migration plan" [59]. The provisions of the law are aimed primarily at facilitating the realization of effective returns, especially in the case of third-country nationals who notoriously keep avoiding cooperation at the realization of the return. In accordance with paragraph 60b, a new residence permit was introduced in the form of "tolerance for persons with unexplained identity", which is issued to third-country nationals whose expulsion cannot take place, due to the fact that they create obstacles which prevent deportation. The obstacles defined in the act include fraud concerning one's identity and a lack of initiative in obtaining a travel document, which would not entail, and this is a key word here, an "excessive burden on the foreign national" [60].

The act also narrows down the understanding of the term "reasonable grounds to suspect absconding", which is one of the provisions for placing a foreign national with an obligation to return in detention [61]. The act enumerates six provisions justifying the determination whether there exist reasonable grounds to suspect absconding and in the light of the way the said Article is drafted, it should be assumed that the list is of a closed character (par. 62(3a)). It is worth mentioning that the said catalogue includes, for instance, fraud committed by a foreign national regarding his identity, failure of a foreign national to appear in person for an interview, the expiration of the period to return, previous evasion of return or a prominent statement on the lack of will to cooperate in the realization of the return. What is interesting, the act was amended in paragraph 62 with paragraph 3b, which, as it were, specifies the circumstances listed in paragraph $3 \mathrm{a}$. The concrete provisions of the risk of absconding listed in the act include, among others, situations when a foreign national participated in the smuggling procedure in order to get into the territory of Germany from a third country, additionally paying the guides; when a foreign national poses a significant threat to the health and life of third persons or legal goods of considerable value related to the internal security; when a foreign national was convicted several times with at least one sentence of imprisonment for a crime committed intentionally; resides illegally in Germany without having a permanent place of residence and due to that remains unavailable to institutions.

The act also regulates the procedure of detaining a for- 
eign national for the period of ten days in order to remove him from the country. Such detention may occur irrespective of the fact whether the conditions for placing him in detention are met and it is executed by order of the court. Moreover, the authority competent to examine the request for deportation was mandated to be able to detain a foreign national without a prior court order under the said law provided that the conditions under par. $62 b(4)(1-3)$ [62] are met. However, after detention, the foreign national should without delay appear before the court so that a decision on detention with a view to removing a foreign national from the country is issued.

In 2019 the Federal Republic of Germany also introduced The Third Law on the Modification of Benefits for Asylum-Applicants [63], which regulates the rules of studying and traineeships in enterprises by the persons seeking international protection, The Law for the Improved Registration and Data Exchange regarding Asylum and Immigration Purposes [64] and The Regulation on the Amendment of the Regulation on the Integration Law and the Employment Regulation [65-67]. A package of laws prepared in such a way allowed for the consolidated adoption of the necessary improvements in migration law.

\subsubsection{Polish legislation in the area of asylum and returns after the migration crisis}

In comparison with Italy and Germany, Poland did not decide to radically reform migration law after the escalation of the crisis in 2015. It resulted primarily from the fact that the Republic of Poland, as a typical transit country, did not experience in the recent years any significant influx of third-country nationals seeking international protection.

Secondly, in the Polish national legal system, migration issues are regulated in a synthetical way by two fundamental legal acts: The Act on Foreigners of 2013 and the Act on granting protection to foreigners within the territory of the Republic of Poland dated 2003-both amended on several occasions [68]. The last significant amendments in the area of refugee and return law concerned, among others, the introduction of the so-called procedure of fast-track examination of applications for international protection (Art. 39 of the Act on granting protection, as amended in 2019), which might be applied, among others, in the case when a foreign national gives incoherent evidence regarding alleged persecution in the country of origin, "submitted an application merely to delay or interrupt the execution of the decision to obligate a foreign national to return" or "poses a threat to state security or public order or was for that reason previously removed from the territory of the Republic of Poland" [69]. Fast-track procedures were recognized by the Court of Justice of the EU as compliant with the rules of the Common European Asylum System and the guarantees of the Procedure Directive (formerly Directive 2005/85, currently Directive 2013/32) [70]. In 2019, the provision of the Act on granting protection under Art. $86 \mathrm{f}$ was amended (Providing public information on the threat for the defense or security of the state from a foreign national). It allows for not qualifying for relocation or resettlement a third-country national who could pose a threat for the defense or security of the state or for the protection of security and public order. To sum up, the changes in Polish law were not of a systemic character.

\subsection{Practical Application of Migration Law in Italy, Germany and Poland}

For the realization of the research objectives of the current article, the case law of the national courts of Italy, Germany and Poland, as well as that of international courts examining the cases from the said countries came under scrutiny.

\subsubsection{Italian post-crisis case law}

The Italian courts are characterized by a high level of jurisprudential activism with regard to migration mattersboth on the level of lower courts (tribunali ordinari, corti d'apelllo), as well as the supreme court (Corte suprema di cassazione).

On the basis of the conducted analysis of the judgements handed down by national courts, it transpires that they are based on the legal norms guaranteeing the protection of human rights. To a large extent, national courts rely on legal international obligations from the area of refugee law and human rights. At the level of tribunal ordinary and corti de apello, it is worth mentioning the judgement by Tribunale di Genova of January 10, 2020 in which the Tribunal granted subsidiary protection to a citizen of Nigeria on the ground that she could be exposed to the risk of inhuman treatment in the case of return to her country of origin $[71,72]$.

Moreover, a broad currently ongoing discussion in Italy concerns the granting of humanitarian protection. An interesting judgement in this area was handed down by the court of appeals in Bologna, which upheld the judgement of the court of first instance, granting protection for humanitarian reasons to a citizen of Ukraine from the region of Ternopil. The granting of protection was justified by the worsening living conditions of the applicant due to the ongoing conflict in the Donbass region [73,74]. This judgement is interesting in as much as Ukraine in general is considered to be a refugee state due to the fact that it preserves its territorial integrity and internal migrations are possible within the Ukrainian territory. Likewise, the Ukrainian authorities are expected to offer assistance in the case of the so-called internal displacements.

Another practical issue in the asylum system in Italy concerns the reception of third-country nationals. An interesting judgement in this respect was handed down by the Administrative tribunal for the Veneto Region, which cancelled the decision of administrative authorities suspending access to reception benefits for an asylum seeker who was aggressive and did not cooperate with the authorities in the course of the procedure. The Tribunal took a stance that behaviors justifying the refusal of reception benefits were not proven [75]. 
From among the judgements by the courts of a lower level in migration cases, it is worth mentioning the judgement of Tribunale di Roma of November 28, 2019 in which the court allowed the right to compensation with regard to fourteen foreign nationals expelled collectively to Libya on the grounds of the agreement of cooperation signed by Italy and Libya [76]. Collective expulsions are banned under Art. 4 of the Additional Protocol no. 4 to the European Convention on Human Rights, whereas the agreement between Italy and Libya allowing for transfers of irregular migrants was criticized on multiple occasions by human rights defenders [77]. Unfortunately, everything seems to indicate that the government of the Italian Republic does not see the threats to which it exposes migrants by sending them back to Libya. This is further strengthened by the decision to continue cooperation with the African partner, undertaken at the beginning of this year [78]. Such a direction of Italian policy met with strong criticism from, among others, the Council of Europe [79].

The Italian judgement which was especially important was the one handed down on February 21, 2019 by a court in Rome (Tribunale Ordinario di Roma, Sezione Diritti della Persona e Immigrazione). The case concerned the entry of a minor child of a Nigerian national-the mother was staying in Italy and the child in Libya. The national court decided that the child may be granted the right of entry under Art. 25 of the Community Code on Visas, which allows the authorities of the Member States to issue the so-called visa with limited territorial validity, among others, in a situation when a Member State deems it necessary to issue such a visa for humanitarian reasons (Art. 25(1)(a)).

The court held that the issuing of such a visa lies in the best interest of the child and is justifiable both on the grounds of the constitutional guarantees for the protection of human rights (the right to family unity and the right to health-the child of the Nigerian national required immediate medical treatment), a well as under the obligations transpiring from the European Convention on Human Rights (Art. 8-the right to protection of family life), even more so as the current situation in Nigeria (the country of origin of the family) does not guarantee appropriate medical assistance to the child of the foreign national. This ruling constitutes, as it were, the continuation of the line of jurisprudence of the Court of Justice of the $E U$ in the case of $X$ and $X v$. Belgium ( $C$ 638/16) in which the Court held that the issuing of humanitarian visas is possible only on the grounds of national law, and not the Union law [80].

The Italian Supreme Court (Corte Suprema di Cassazione) also remains active in migration cases. From among the judgements issued in the years 2018-2019, it is worth citing primarily the judgement of November 13, 2019 [81], in which the Court held that social integration of the migrant is not a sufficient condition to grant such a person authorization to stay for humanitarian reasons. As it was demonstrated in the previous section of the article, Decreto Salvini limited to a large degree the possibility of granting authorization to stay for humanitarian reasons. Despite the fact that the ruling of the court upheld the stance of the government, it is not contrary to international obligations due to the fact that the authorization to stay for humanitarian reasons is issued to persons whose return to their country of origin would expose them to inhuman treatment $[82,83]$.

However, it seems that the Supreme Court in Italy is a court adopting a pro-human-rights line of jurisprudence, taking into consideration the recent case law in migration matters. Such an opinion may be justified by a ruling issued also on November 13, 2019, in which the court excluded retroactive application of the Decreto Salvini with regard to third-country nationals who submitted application for international protection before October 5, 2018 [84]. Moreover, in the judgement handed down on October 10, 2019, the Supreme Court obligated the judges who ruled in the first and second instance on migration cases to refer to the information on the countries of origin in the cases in which the granting of subsidiary protection status was refused [85]. An exceptionally broad interpretation of the concept of "legally residing foreigner" for the purpose of acknowledging the right of a foreign national to legal aid was made by the Supreme Court in the ruling of January 5, 2018. The court took a stance that a broader interpretation of the concept should also include situations in which a foreign national remains in the procedure which might hypothetically result in the granting of international protection or a residence permit. In the opinion of the court, a foreign national may be deemed as "irregular" only after the issuing of the decision ordering his return to the country of origin, but even then, he should be entitled to legal aid, if he is to appeal against that decision [86].

Undoubtedly, one of the best-known cases in Italy in recent years was the case of Carola Rackete, captain of the sea rescue ship Sea Watch 3, which took on board 53 persons on international waters on June 12, 2019. The migrants included nationals of Nigeria, Guinea, Cameron, Mali, Ivory Coast, Ghana, Burkina Faso and Guinea-Conakry. The ship captain justified her rescue activities as acting under Art. 98 of the Montego Bay Convention. Due to the legge 53/2019 adopted in Italy, the Minister has competence to issue a prohibition of entry of a ship into the port. This is what happened in the case of Sea Watch 3. Captain Rackete decided that the nearest safe harbor for the migrants would be Lampedusa (in her opinion, neither the ports in Libya nor Tunis could be considered safe, as Tunis is not party to the Geneva Convention of 1951). On June 21, 2019 she applied to the European Court of Human Rights for the issuing of the interim measure allowing for disembarkation, justifying the need for such a measure with the guarantees under Art. 2 and 3 of the European Convention on Human Rights. The Court refused to grant interim measures on June 25, 2019 [87] and in consequence Sea Watch 3 entered the harbor in Lampedusa without authorization, colliding with sea patrol boats which tried to intercept her. Captain Rackete was arrested, however, in the ruling issued on June 30, 2019 the court in Agrigento cleared her of all the charges [88]. In the justification it was emphasized that 
Captain Rackete's actions were within law_especially with regard to Art. 18 of the Convention on the Law of the Sea, defining the term "passage" in accordance with which "[it] includes stopping and anchoring, but only in so far as the same are incidental to ordinary navigation or are rendered necessary by force majeure or distress or for the purpose of rendering assistance to persons, ships or aircraft in danger or distress" (Art. 18(2)). Apart from that, justification for Captain Rackete's actions could be found under Art. 10 decreto legislative 286/98, in accordance with which refoulement is not to be executed in the case of matters relevant to international protection (Art. 10(4)) [89].

\subsubsection{Post-crisis case law in Germany}

Even a cursory analysis of the jurisprudence of the German courts in asylum and return cases highlights the basic difference of this case law in comparison to that of Italian courts. Indeed, German cases concern primarily the issues regarding the provisions of the Dublin Regulation, that is the one that is currently in force: Regulation (EU) no. $604 / 2013$ of the European Parliament and of the Council of June 26, 2013 establishing the criteria and mechanisms for determining the Member State responsible for examining an application for international protection lodged in one of the Member States by a third-country national or a stateless person ([90], pp. 31-59).

The first group of rulings which were handed down in the years 2018-2019 was quite numerous and concerned the prohibition of the transfer of foreign nationals from Germany to other Member States. In accordance with regulation $604 / 2013$, the initiation of the transfer procedure occurs on the grounds of Art. 21 of the Regulation 604/2013. German administrative courts ruled on the prohibition of transfers to the countries of origin, in which persons seeking international protection might be exposed to the risk of inhuman treatment. This was the situation concerning a single mother of Syrian nationality, who was to be returned together with her three children to Romania [91]. In the judgement, the administrative court in Düsseldorf justified the prohibition of transfer with the possibility of exposing the family, entirely dependent on state aid, to deprivation and the risk of breaching their personal dignity. What is also significant, the administrative court referred in its reasoning to the judgement of the European Court of Human Rights in the case of Tarakhel [92]. Further, the Federal Administrative Court of Germany in the ruling of August 20, 2018 upheld the judgement of the administrative court of Lower Germany handing down that the return of foreign nationals from Germany to Bulgaria would expose them to the risk of inhuman treatment [93]. German courts expressed their negative opinions also on the subject of transfers from Germany to Italy - this is was the stance of the administrative court in Augsburg in the ruling of November 2, 2018, stating in its reasoning that there was a lack of individual guarantees from the side of Italy and referring to the ruling in the case of Tarakhel [94]. In the judgement of April 25, 2019, the administrative court in Arnsberg ruled that the transfer from Germany to France be suspended on the grounds of a possible breach of Art. 3 of the European Convention of Human Rights.

A similarly negative stance on the subject of the transfer of a foreign national to Greece was taken by the administrative court in Magdeburg. In the judgement of November 13,2018 , the court ruled the interim measure with regard to a third-country national who was given refugee status in Greece and then submitted an application for protection in Germany. The German court held that the return of the migrant to Greece would expose him to a real risk of inhuman treatment [95].

A prohibition of the transfer to Greece was also handed down by the Administrative Court in Bavaria (judgement of May 9, 2019). However, the case was atypical in as much as it concerned the execution of return on the grounds of a bilateral agreement concluded between Germany and Greece, before the initiation of the transfer procedure under the Dublin Regulation. The administrative court in Munich also expressed its doubts with regard to the so-called "pre-Dublin procedure" [96]. The case concerned an Afghan seeking international protection who was returned to Greece on the grounds of the bilateral agreement-the administrative court ordered that the third-country national's re-entering Germany from Greece should be facilitated in such a way as to fully guarantee the foreign national his rights resulting from the Dublin Procedure.

The prohibition of transfer of a Syrian national to Greece on the grounds of the Dublin Procedure was handed down by the Administrative Court in Munich (ruling of July 17, 2019). The foreign national submitted an application for refugee status in Greece, but his application was recognized as inadmissible due to the fact that the Syrian arrived in Greece from Turkey and it was Turkey that was considered to be "The First Country of Asylum". The German court pointed out that in the case of a transfer of a thirdcountry national to Greece, he was at risk of the so-called chain refoulement to Turkey, which in the court's view did not effectively implement the provisions of the Geneva Convention Relating to the Status of Refugees of 1951.

What is more, German courts also interpreted other provisions of the Dublin Procedure [97], among others, Art. 28 of the Regulation, concerning the guarantees regarding detention for the purpose of transfer. The Higher Administrative Court of Lüneburg ruled in the case $13 \mathrm{ME} 442 / 17$ and in the judgement of January 22, 2018 found the reporting obligations, provided for in German law, that is, in this case obliging a third-country national to remain in the accommodation center for the night as a measure to ensure that the transfer is carried out as unlawful.

A special place in the case law of German courts is occupied by the cases concerning family reunification. In this field, the case law was pro human rights. To give some examples, in the judgement of September 4, 2018, the Higher Administrative Court of Berlin-Brandenburg ruled on the possibility of family reunification and the necessity 
of granting an interim measure in the case when a minor who is subject to family reunification is soon to be eighteen years of age [98]. Further, the administrative court in Munster ruled that due to the existing risk of violating the fundamental right to family unity, in the best interest of the child, the German administrative bodies should accept the take chargé request from Greece, submitted after the expiry time limit, so as to allow the Syrian siblings family reunification [99]. In a similar way and on the basis of the jurisprudence of the Court of Justice of the EU (judgement in the case of $X$ and $X$ ) [100], the administrative court in Berlin held that the rejection of the take chargé request from Greece by migration authorities was unlawful. However, as the court emphasized, the legal norms contained in the Dublin Regulation should be interpreted in the light of Art. 8 of the European Convention of Human Rights and to protect the best interest of the child.

\subsubsection{Polish case law after the migration crisis}

In the post-crisis period, Polish courts had to face entirely different problems. The cases concerning foreign nationals are usually proceeded by administrative courts, as the procedures regarding the refugee status are examined in the administrative procedure and in the majority of cases migrants appeal against the decisions refusing refugee status or against the decisions refusing entry to the territory of the Republic of Poland [101].

The first and probably the most reported issue concerns the refusal of entry with regard to foreign nationals who declare the willingness to apply for refugee status and arrive at the border in Terespol. Terespol is a border crossing point between Belarus and Poland and therefore it is located on the external border of the EU. Terespol is a border crossing point for third-country migrants, especially from Chechenia, who want to get to the European Union via Belarus and receive international protection on account of being persecuted in their country of origin. Having declared an intention to apply for the refugee status, such persons should be directed for further assessment and subjected to a detailed examination regarding their personal situation. However, as it transpires from the reports and case law presented below, third-country nationals are refused the opportunity to lodge an application, despite the fact that they often arrive at the border crossing point multiple times. In such cases, they are sent back to Belarus, where they might experience further persecution due to the dependence of the Belarus regime on Russia.

This issue was analyzed in greater detail in an article prepared by the Helsinki Foundation for Human Rights and published in April 2019 [102]. On the basis of the analyzed material, it transpires that the complainants challenging the decisions refusing entry declared that they were willing to apply for refugee status and therefore, under the law, there was no possibility to issue a negative decision in this respect ([102], p. 31). The authors of the report state that as of the day of drafting the report, the Provincial Administrative
Court (WSA) in Warsaw ruled in 59 of such complaints and in 25 cases quashed the decisions which were unfavorable for foreign nationals [102]. Moving further, 33 rulings of the Provincial Administrative Court were brought before the Supreme Administrative Court (NSA) as a cassation complaint. In its line of jurisprudence, the NSA focused on the interpretation of Art. 28 of the Act on foreigners. In the view of the court, the provisions of this Article should be interpreted in the light of the principle of non-refoulement [103]. The Supreme Administrative Court held in its rulings that the border guards, that is administrative agencies, were obligated to determine the factual reasons of a foreign national's entry into the territory of Poland and therefore there were no grounds for applying Art. 34(2) of the Act on foreigners, in accordance with which, "Activities undertaken as part of the proceedings referred to in paragraph 1 may be limited to checking only the documents held by the foreigner if the grounds for the foreigner's failure to meet the conditions required to cross the border do not raise any doubts".

To illustrate the above, in the reasoning of the judgement rejecting the cassation complaint and therefore acknowledging that a foreign national was right in filing for revoking of the decision, the Supreme Administrative Court held that "Even if at the border crossing point there occurred some instances of certain misuse of the refugee procedure by some foreign nationals who used the key words "asylum" or "refugee" without the actual understanding of their meaning, and even if the Border Guard is facing organizational challenges with regard to managing border control activities for a large number of foreign nationals who do not have visas or any other residence titles entitling them to enter into and stay on the territory of Poland, which results in, e.g. a considerable shortening of the time that could be devoted to one person, the above cannot justify such laconic documentation of the course of the interview with a foreign national on the so-called "second line" as that that can be found in the present case file in the report of [...] February 2017 [104]. In the further part of the reasoning, the formation of the court emphasized that the first instance court rightly held that the administration agency, in this case the Border Guard, prematurely concluded that the case was obvious and did not require any further inquiry.

In the examined cases, the Supreme Administrative Court emphasized that the interviewing of the foreign national at the border should occur in the presence of a legal representative [105]. The seriousness of the issue regarding refusals of entry issued to foreign nationals wanting to apply for international protection is also emphasized by the cases directed to the European Court of Human Rights, as for instance in the case of D.A. and others v. Poland [106] or in the case of M.A. and others v. Poland [107].

An especially important role in the process of protecting migrants' rights in Poland, including also persons seeking international protection is played by the Office of the Ombudsman. The Ombudsman visits the borders, including its most problematic section in Terespol [108] and actively exercises his powers conferred on him by the Act on the 
Ombudsman [109]. An example of the Ombudsman's successful intervention is the fact that the NSA took account of a cassation complaint submitted by the Ombudsman in the case concerning a national of Chechenia who was refused international protection. In the judgement of December 18, 2019, the Supreme Administrative Court referred the case back for re-examination deciding that the Council on Refugees had not fully explained the factual aspects of the matter [110,111].

The administrative courts in Poland also deal with return cases, that is, appeals against the decisions obligating to return. Indeed, in the judgement of September 19, 2019, the Supreme Administrative Court dismissed the cassation appeal of the Head of the Office for Foreigners [112]. The complainant in the case waived her right to appeal against the return decision after it was orally translated to her and after she signed a required statement. In the opinion of the court of the first instance, the foreign national concerned was not properly informed, in accordance with the existing procedures, about the consequences of the renouncing of the right to appeal, as such information should be conveyed in writing and in the language understood by the foreign national. This stance was upheld by the formation of the court of the Supreme Administrative Court.

A practical problem in the management of migration movements in Poland is also the issue of detention of families with children. Despite the judgement of the European Court of Human Rights in the case of Bistieva and others v. Poland [113] there still occur cases of neglecting the best interest of the child. As a result, the Helsinki Foundation for Human Rights addressed a speech on this subject to Prof. Felipe González Morales, the United Nations Special Rapporteur on the human rights of migrants [114].

\section{Conclusion}

The analysis of legal provisions and the case law in migration matters conducted in the article does not allow for offering a definitive answer to the question whether in Italy, the Federal Republic of Germany and Poland the principle of migration security priority and the right to migration security are realized at the national level. Such an ambiguous answer to the research question does not result from insufficient background research into the substance of the matter and its analysis, but from the very character of national legislation-a large number of scattered legal acts, various modifications and primarily the character of migration policy realized by the Member States. Traditionally, national states protect their sovereignty and prioritize the protection of national security and public order, whereas the acts of EU law facilitate the harmonization of actions at the level of the EU and the implementation of the standards of the protection of migrants' rights in a more effective way. In as much as the Union has the possibility of harmonization (through directives) and unification (through regulations) of the standards on treatment of third-country nationals, it does not possess the competence to introduce common standards with regard to the issues of national security, which remain within the competence of the Member States.At the legislative level, the Member States focus primarily on ensuring security to the receiving society. Even if it is justifiable to say that the adopted changes safeguard a higher level of security, it concerns in the first place, public security (Italian and German acts) and not the security of the migrant as a fully-fledged participant of the migration process. Hence, on the basis of the analyzed legal acts, especially Italian and German legislation, it appears reasonable to claim that, unfortunately, the national law protects to a greater degree the security of the host country and in this way, it decreases the protection of the interests of foreign nationals seeking international protection or remaining under the return procedure.

With regard to the axiological model of migration security discussed at the beginning of the present study, it should be noted that, to a large degree, it is implemented in the jurisprudence of national courts. The application of asylum and return law should be exercised with a special inclusion of the postulate of solidarity and the protection of migrants' rights. The analyzed case law of the Polish, German and Italian courts clearly indicates that they adopt a pro human rights approach and make the best interest of the migrant their priority.

With reference to the postulate of creating an ideal national system of migration law discussed at the beginning of the article, it appears that in the current legal situation and due to the division of competence between the EU and the Member States, it might seem difficult to accomplish. First of all, it might be due to a lack of instruments of direct democracy and no direct possibility for the people to take a stance with reference to the shape of migration policy (right to self-determination). There is no doubt that even in the case of resorting to the instrument of referendum, voters would need an objective information campaign especially on the contribution of migrants into the economic life of the receiving society. Nevertheless, what is of significant importance for the creation of the national legal system is the guarantees of EU law with regard to the protection of migrants' fundamental rights, which remain, in fact, irrebuttable (in accordance with Art. 18 and 19 of the Charter of Fundamental Rights and the provisions of the Treaty on the Functioning of the European Union), constituting a certain safety buffer for migrants in the legal regulations passed by national legislators in the Member States. The implementation of the principle of solidarity and commonality is also protected by EU law and the directives adopted within the Area of Freedom, Security and Justice, as the governments of the Member States are rather focused on the protection of their particular interests. Integration remains a challenge for the future, but there is no question that the shaping of fair rules in this area will also belong to the EU, whereas the effective imple- 
mentation of those regulations will remain in the hands of the Member States.

A postulate which, hopefully, might be more feasible to realize in the future is that of increasing the importance of the right to self-determination and making the voice of civil society be heard by the governments. Without doubt, the increasing activity of the organizations from the third sector serves this purpose and their pursuits may well provide ample material for further study.

\section{References and Notes}

[1] The current article is based on the findings of the research project entitled "Zarządzanie bezpieczeństwem w prawie i polityce azylowej i powrotowej Unii Europejskiej w obliczu kryzysu migracyjnego" (Security Management in European Asylum and Return Law and Policy with Regard to the Migration Crisis) registered at no. 2016/23/D/ HS5/00404 and funded by the National Science Centre, Poland.

[2] Kosińska AM. The Creative Role of the European Council in the Area of Managing Asylum Migration and Return of Third-Country Nationals to Their Country of Origin in the Times of the Migration Crisis. Research on the Content of the EC's Conclusions 2011-2017. In: Yearbook of Polish European Studies. vol. 20. Centre for Europe, University of Warsaw; 2017. pp. 101-127.

[3] Treaty on the Functioning of the European Union. European Union; 2016. C202. Available from: https://eur-lex.europa.eu/legalcontent/EN/TXT/PDF/?uri=OJ:C:2016:202:FULL\&from=EN.

[4] Hartley T. The Foundations of European Union Law. Oxford University Press; 2010. doi:10.1093/he/9780199566754.001.0001.

[5] Lelieveldt H, Princen S. Analysing the EU. In: The Politics of the European Union. Cambridge University Press;. pp. 31-50. doi:10.1017/cbo9780511984693.003.

[6] Dawson M. The Governance of EU Fundamental Rights. Cambridge University Press; 2017. doi:10.1017/9781107707436. The author also emphasizes that the Fundamental Rights Governance in the EU is based on the principle of exercising the above rights in certain specific political communities. Hence, the key role in the realization of those guarantees is played by the constitutional systems of the Member States.

[7] Annual Report on the Situation of Asylum in the European Union 2015. European Asylum Support Office; 2016. doi:10.2847/704455.

[8] Communication from the Commission to the European Parliament, the Council, the European Economic and Social Committee and the Committee of the Regions. A European Agenda on Migration. Brussels, BE: European Comission; 2015. $\operatorname{COM}(2015) 240$ final. Available from: https://ec.europa.eu/anti-trafficking/sites/antitrafficking/files/ communication_on the european_agenda_on migration_en.pdf.

[9] Council Decision (EU) 2015/1601 of 22 September 2015 establishing provisional measures in the area of international protection for the benefit of Italy and Greece. European Union;. L 248/80. Available from: https://eur-lex.europa.eu/legal-content/EN/TXT/PDF/ ?uri=CELEX:32015D1601\&from $=E N$.

[10] Policy Department C: Citizen's Rights and Constitutional Affairs. Internal Border Controls in the Schengen Area: Is Schengen CrisisProof, Study for the LIBE Committee. European Parliament; 2016. Available from: https://www.europarl.europa.eu/RegData/etudes/ STUD/2016/571356/IPOL_STU\%282016\%29571356_EN.pdf.

[11] Kosińska AM, Barbara M. Does the Right to Migration Security AIready Exist? Considerations from the Perspective of the EU's Legal System. European Journal of Migration and Law. 2019;21(1):83116. doi:10.1163/15718166-12340043.

[12] Rosenblum MR, Tichenor DJ. The Oxford Handbook of the Politics of International Migration. Oxford University Press; 2012. doi:10.1093/oxfordhb/9780195337228.013.0001.

[13] El-Enany N. The 'New Europe' and the 'European Refugee': The Subversion of the European Union's Refugee Law by its Migration Policy. In: Juss SS, editor. The Ashgate Research Companion to Migration Law, Theory and Policy. 21. Routledge; 2013. pp. 3-24.

\section{Acknowledgments}

This paper is based on the findings of the research project entitled "Zarządzanie bezpieczeństwem w prawie i polityce azylowej i powrotowej Unii Europejskiej w obliczu kryzysu migracyjnego" (Security Management in European Asylum and Return Law and Policy with Regard to the Migration Crisis) registered at no. 2016/23/D/ HS5/00404 and funded by the National Science Centre, Poland.

doi:10.4324/9781315613239.

[14] Bowling B. Epilogue: The Borders of Punishment: Towards a Criminology of Mobility. In: The Borders of Punishment. Oxford University Press; 2013. pp. 291-306. doi:10.1093/acprof:oso/9780199669394.003.0017.

[15] Heath Wellman C, Cole P. Debating the Ethics of Immigration. Oxford University Press; 2011. doi:10.1093/acprof:osobl/9780199731732.001.0001.

[16] Vigneswaran D. Territory, Migration and the Evolution of the International System. Palgrave Macmillan UK; 2013. doi:10.1057/9780230391291. The author also points out to a very interesting term "territoriality", which is defined as "strategies that affect, influence or control people, phenomena and relationships, by delimiting and asserting control over a geographic area".

[17] Stevens D. The Humaneness of EU Asylum Law and Policy. In: Ferreira N, Kostakopoulou D, editors. The Human Face of the European Union. Cambridge University Press; 2018. pp. 235-259. doi:10.1017/cbo9781139924795.011.

[18] Miller D. Strangers in Our Midst. Harvard University Press; 2018. doi:10.4159/9780674969827.

[19] de Bruycker P. Elements for a New European Consensus on Migration and Asylum. In: de Bruycker P, de Somer M, editors. Towards a New European Consensus on Migration; 2019. pp. 145-159. Available from: https://odysseus-network.eu/from-tampere-20-totampere-2-0-towards-a-new-european-consensus-on-migration/.

[20] The author also adds the following: common funding and common positioning towards third countries.

[21] Haddad E. The Refugee in International Society: Between Sovereigns. Cambridge University Press; 2008. doi:10.1017/CBO9780511491351.

[22] Grey C. Justice and Authority in Immigration Law. Bloomsbury Publishing. 2017; Available from: https: //www.bloomsburyprofessional.com/uk/justice-and-authorityin-immigration-law-9781509915446/.

[23] Kosińska AM. Prawa kulturalne obywateli państw trzecich w prawie Unii Europejskiej. 2018; Available from: https://books-box.com/katalog/wydawnictwo-kul-katolickiegouniwersytetu-lubelskiego/prawa-kulturalne-obywateli-panstwtrzecich-w-prawie-unii-europejskiej. As the author explains: "The living together principle, which the European Court of Human Rights referred to in a famous ruling in the case of S.A.S., presumes a restriction of the rights of an individual as an element of protection of the rights and freedoms of others, facilitating a harmonious social co-existence within the framework of civil society".

[24] Trispiotis I. Two Interpretations of "Living Together". In: European Human Rights Law. vol. 75. Cambridge University Press (CUP); 2016. pp. 580-607. doi:10.1017/s0008197316000568.

[25] Judgement of the European Court of Human Rights of 1 July 2014 in the case of S.A.S. v. France, complaint no. 43835/11. Strasbourg, France: European Court of Human Rights; 2014. Available from: http://hudoc.echr.coe.int/eng? $\mathrm{i}=001-145466$.

[26] Carens J. The Ethics of Immigration. Oxford University Press; 2013.

[27] Pajnik M. 2016;pp. 239-257.

[28] Okólski M. Transition from Emigration to Immigration. In: European Immigrations. Amsterdam University Press; 2012. pp. 23-44. doi:10.1515/9789048517275-002.

[29] Barankiewicz T. Współczesne metody badania prawa Barankiewicz Tomasz | Polona. Studia Prawnicze KUL. 2010;41(1). Available from: https://polona.pl/item/wspolczesne- 
metody-badania-prawa, MjE3NjMzNzA/

[30] Decreto-legge 4 ottobre 2018, n. 113, Disposizioni urgenti in materia di protezione internazionale e immigrazione, sicurezza pubblica, nonche' misure per la funzionalita' del Ministero dell'interno e l'organizzazione e il funzionamento dell'Agenzia nazionale per l'amministrazione e la destinazione dei beni sequestrati e confiscati alla criminalita' organizzata;.

[31] Legge 1 dicembre 2018, n. 132, Conversione in legge, con modificazioni, del decreto-legge 4 ottobre 2018, n. 113, recante disposizioni urgenti in materia di protezione internazionale e immigrazione, sicurezza pubblica, nonche' misure per la funzionalita' del Ministero dell'interno e l'organizzazione e il funzionamento dell'Agenzia nazionale per l'amministrazione e la destinazione dei beni sequestrati e confiscati alla criminalita' organizzata. Delega al Governo in materia di riordino dei ruoli e delle carriere del personale delle Forze di polizia e delle Forze armate;.

[32] See, for instance: https://www.theguardian.com/world/2015/jun/13/ lega-nord-migrants-rome-stand-off-luca-zaia.

[33] I problemi della 'sicurezza': I'impatto psicologico e psicosociale della legge 132/2018; Documento della Associazione Italiana di Psicologia. Associazione Italiana di Psicologia; Associazione per gli Studi Giuridici sull'Immigrazione; 2019. The doubts concerning the adopted solutions and the treatment of migrants as, per se (a priori) threats to the security of the state were expressed by, among others. Available from: http://www.asgi.it/wpcontent/uploads/2019/04/2019_AIP_psicologia_immigrazione.pdf.

[34] Benvenuti $M$. II dito e la luna. La protezione delle esigenze di carattere umanitario degli stranieri prima e dopo il decreto Salvini. Diritto, Immigrazione e Cittadinanza. 2019;(1). Available from: https://www.dirittoimmigrazionecittadinanza.it/archivio-saggicommenti/saggi/fascicolo-n-1-2019-1/345-il-dito-e-la-luna-laprotezione-delle-esigenze-di-carattere-umanitario-degli-stranieriprima-e-dopo-il-decreto-salvini/file.

[35] Loprieno D. II trattenimento dello straniero alla luce della I. n. 132 del 2018. Diritto, Immigrazione e Cittadinanza. 2019;(1). Available from: https://www.dirittoimmigrazionecittadinanza.it/archivio-saggicommenti/saggi/fascicolo-n-1-2019-1/337-il-trattenimento-dellostraniero-alla-luce-della-I-n-132-del-2018.

[36] The doubts concerning the compatibility of such solutions with fundamental rights guaranteed in the EU were expressed by the European Fundamental Rights Agency (FRA).

[37] Beyond the Peak: Challenges Remain, but Migration Numbers Drop. Access to Asylum. Asylum, Migration and Borders. Annual Review. European Union Agency for Fundamental Rights (FRA); 2019. doi:10.2811/069603.

[38] Vita, febbraio 2019. Seicento psicoanalisti scrivono a Mattarella contro il Decreto Sicurezza. Società Psicoanalitica Italiana; 2019. The same was also expressed by Italian NGOs - among others, Societa Psicoanalitica Italiana - a petition against the decree was signed by 600 psychoanalysts.

[39] Migration and Home Affairs. Humanitarian Protection. European Commission. In Germany, the idea of granting "permits on humanitarian grounds" is close to the one which functioned before the adoption of the Salvini decree. Available from: https://ec.europa.eu/ home-affairs/pages/glossary/humanitarian-protection_en.

[40] What is interesting, the objection of non-constitutionality concerns legal changes facilitating the revocation of Italian nationality in the case of committing terrorist offences, which, in the opinion of $\mathrm{C}$. Corsi, leads to the breach of the constitutional principle of equality of citizens and the introduction of the new status civile. It remains an open question in the discussion whether the changes adopted in Italy are meant to counteract the return of militants.

[41] Corsi C. Evaluating the "Salvini Decree": Doubts of Constitutional Legitimacy. Policy Briefs. 2019;(6). doi:10.2870/199546.

[42] Constituzione della Repubblica Italiana. Gazzetta Ufficiale della Repubblica Italiana. 1947;(298). Available from: https://www. gazzettaufficiale.it/anteprima/codici/costituzione. In accordance with Art. 10 of the Constitution of the Italian Republic: "The Italian legal system conforms to the generally recognized principles of international law. The legal status of foreigners is regulated by law in conformity with international provisions and treaties".

[43] Forsythe DP. Humanitarian Protection: The International Com- mittee of the Red Cross and the United Nations High Commissioner for Refugees. $2001 ; 83(843): 675-697$. Available from: https: //www.icrc.org/en/doc/assets/files/other/675_698_forsythe.pdf.

[44] See, for instance: Judgement of the ECtHR of 15.12 .2016 in the case of Khlaiffia and Others v. Italy, application no. 16483/12, Judgement of the ECtHR of 16.11.2016, Hirsii Jamaa and Others v. Italy, application no. 27765/09.

[45] Non-refoulement as a Principle of International Law and the Role of the Judiciary in its Implementation, Dialogue between judges 2017, Council of Europe 2017. European Court of Human Rights; 2017. Available from: www.echr.coe.int.

[46] It concerns the reintroduction of the maximum period of detention, which in accordance with the EU law lasts 180 days, in place of the 90-day pre-removal detention period established in 2012.

[47] Italy Immigration Detention Profile, January 2018, 6. Global Detention Project;. Available from: https://www.globaldetentionproject. org/.

[48] What is significant, the report states that "According to the Senate Extraordinary Commission for the Promotion of Human Rights, the average detention period in Italy's long-term detention centers during 2015 was 25.5 days." (p. 7). In view of the above, it is even more difficult to understand the reversal of the positively-regarded reform of the Turco-Napolitano Act.

[49] Case of Tarakhel v. Switzerland. European Court of Human Rights; 2014. 29217/12. Available from: https://www.asylumlawdatabase.eu/en/content/ecthr-tarakhelv-switzerland-application-no-2921712.

[50] Country Report Italy, Asylum Information Database (AIDA), FRA, Italy 2018. Asylum Information Database (AIDA); 2018. Available from: https://www.asylumineurope.org/reports/country/italy.

[51] Decreto-legge 14 giugno 2019, n. 53. Disposizioni urgenti in materia di ordine e sicurezza pubblica. (19G00063) (GU n.138 del 14-62019). Gazzetta Ufficiale della Repubblica Italiana. 2019; Available from: https://www.gazzettaufficiale.it/eli/id/2019/06/14/19G00063/ sg.

[52] Legge 8 agosto 2019, n. 77. Conversione in legge, con modificazioni, del decreto-legge 14 giugno 2019, n. 53, recante disposizioni urgenti in materia di ordine e sicurezza pubblica (19G00089) (GU Serie Generale n.186 del 09-08-2019). Gazzetta Ufficiale della Repubblica Italiana. 2019; Available from: https: //www.gazzettaufficiale.it/eli/id/2019/08/09/19G00089/sg.

[53] II DL. n. 53/2019, convertito, con modificazioni, nella L. n. 77 /2019 Analisi critica del c.d. "Decreto sicurezza bis" relativamente alle disposizioni inerenti il diritto dell'immigrazione, 13 settembre 2019. Assocciazione per gli Studi Guridici sul' Immigrazione (ASGI). 2019; Available from: https://www.asgi.it/notizie/decreto-sicurezza-bislanalisi-dellasgi/.

[54] Ministero degli affari esteri e della cooperazione internazionale. Decreto 4 ottobre 2019. Individuazione dei Paesi di origine sicuri, ai sensi dell'articolo 2-bis del decreto legislativo 28 gennaio 2008 , n. 25. (19A06239) (GU Serie Generale n.235 del 07-10-2019). Gazzetta Ufficiale della Repubblica Italiana. 2019; Available from: https://www.gazzettaufficiale.it/eli/id/2019/10/07/19A06239/sg.

[55] Nota di commento del decreto del ministro degli affari esteri e della cooperazione internazionale 4 ottobre 2019 sull'elenco dei paesi di origine sicuri (27 Novembre 2019). Assocciazione per gli Studi Guridici sul' Immigrazione (ASGI). 2019; Available from: http: //www.asgi.it/wp-content/uploads/2019/11/Nota-ASGI-commentod.M.A.E.-4-10-2019-paesi-sicuri-definitivo-27-11-2019.docx.pdf.

[56] Migration: Key Fundamental Rights Concerns, FRA, 1.04.201930.06.2019. European Union Agency for Fundamental Rights (FRA); 2019. 4. Available from: www.fra.europa.eu.

[57] 'We can do this!'-Merkel's Famous Words Five Years on after Refugee Influx to Germany. Made for Minds. 2021; Available from: https://www.dw.com/en/merkel-germany-refugees/a-54769229.

[58] Migration, Asylum and Refugees in Germany: Understanding the Data. Data Briefing Series. 2016;(1). Available from: https://www.iom.int/sites/default/files/country/docs/Germany/ Germany-Data-Briefing-1Jan2016.pdf.

[59] Bundesministerium des Innern, für Bau und Heimat. Available from: https://www.bmi.bund.de/SharedDocs/pressemitteilungen/DE/ 2019/08/geg-geordnete-rueckkehr-gesetz.html. 
[60] The circumstances which do not constitute an excessive burden on the foreign national are believed to be, in accordance with paragraph $60(3)$, the following: cooperation in the issuing and extending of the validity of the passport in accordance with the regulations of the German passport law, personal appearance before the agencies of the country of origin; submitting a statement, before the agencies of the country of origin, on voluntary leaving the federal territory; pay all the fees as defined in the country of origin and applicable under official institutional activities regarding the issuing of a passport; submit another application for a new passport or a document replacing the passport.

[61] In accordance with par. 62(3): By the order of the court, a foreigner is placed in custody (preventive custody) in order to safeguard the possibility of expelling him from the country, if:

1. there is a risk that he/she may abscond

2. on the grounds of unlawful entry into the country the foreigner is obliged to leave its territory in a feasible way or

3. an order was issued to expel a foreigner from the country in accordance with $\S 58 \mathrm{a}$, which, however, cannot be executed with immediate effect".

[62] Such official detention may take place when:

1. there is a high probability that there exist the reasons defined in paragraph 1(1);

2. there is no possibility of obtaining a court ruling on the matter of ordering a detention with a view to expelling the foreigner from the country in the understanding of paragraph 1 , and

3 . There is a justified reason to believe that the foreigner will avoid the execution of the order to detain him with a view of expelling him/her from the country".

[63] Drittes Gesetz zur Änderung des Asylbewerberleistungsgesetzes. Bundesanzeiger Verlag. 2019;18(BGBI. I 2019 no. 31S.1290). Available from: https://www.bgbl.de/xaver/bgbl/start.xav\#_bgbl_ _\%2F\%2F*\%5B\%40attr_id\%3D\%27bgbl119s1290.pdf\%27\%5D_ 1584310711114

[64] Zweites Gesetz zur Verbesserung der Registrierung und des Datenaustausches zu aufenthalts- und asylrechtlichen Zwecken (Zweites Datenaustauschverbesserungsgesetz - 2. DAVG). Bundesanzeiger Verlag. 2019;4(BGBI. I 2019 no. 29 S. 1131). Available from: https: //www.bgbl.de/xaver/bgbl/start.xav\#_bgbl \%2F\%2F*\%5B\% 40attr id\%3D\%27bgbl119s1290.pdf\%27\%5D 1584316059056.

[65] Verordnung zur Änderung der Verordnung zum Integrationsgesetz und Beschäftigungsverordnung. Bundesanzeiger Verlag. 2019;22(BGBI. I 2019 no. 28 S. 1109). Available from: https: //www.bgbl.de/xaver/bgbl/start.xav\# bgbl \%2F\%2F*\%5B\% 40attr_id\%3D\%27bgbl119s1109.pdf\%27\%5D_1565356605528.

[66] As the European Agency for Fundamental Rights observes, the act "abolishes the so-called 'priority check' (Vorrangprüfung), previously required before granting an employment permit to asylum applicants who have resided in Germany for three months or longer. The priority check assessed whether a German national would be available for the job before it was offered to an asylum applicant".

[67] Migration: Key Fundamental Rights Concerns, FRA, 1.07.201930.09.2019. European Union Agency for Fundamental Rights (FRA); 2019. 8. Available from: www.fra.europa.eu.

[68] Act on Foreigners of December 12, 2013, Journal of Laws 2020.35; Act on granting protection to foreigners within the territory of the Republic of Poland of June 13, 2003, Journal of Laws 2019.1666. With regard to the issues related to migration security, Art. 144a was added to the Act on foreigners in 2019 which allows the Minister competent for internal affairs to issue decisions on the prohibition of enrolling a foreigner to a higher education course when "it is required for the reasons of defence or the security of the country or for safeguarding the security of the state and public order" (Art. $144 \mathrm{a}(1)(1))$

[69] See Art. 39(1)(3-5) of the Act on granting protection to foreigners on the territory of the Republic of Poland.

[70] See: Judgment of the Court, 31 January 2013, H. I. D. and B. A. v Refugee Applications Commissioner and Others, C 175/11, ECLI:EU:C:2013:45.

[71] Tribunale di Genova, Sezione XI Civile, Decreto n. cronologico 96/2020, 10.01.2020. European Database of Asylum Law; 2020. Available from: https://www.asylumlawdatabase.eu/en/content/italy- well-founded-risk-inhuman-treatment-case-return-nigeria.

[72] Protezione sussidiaria a richiedente asilo nigeriana: il racconto presenta fortissimi indicatori che portano a ritenere che la stessa benché non lo dichiari apertamente - sia stata vittima di tratta. 2020; Available from: https://www.meltingpot.org/Protezione-sussidiariaa-richiedente-asilo-nigeriana-il.html\#.Xzr3Cadxc2z.

[73] La Corte di Appello di Bologna. Prima Sezione Civile, Sentenza n. 192/2020 pubbl. il 14/01/2020RG. Repubblica Italiana; 2020. Available from: https://www.meltingpot.org/IMG/pdf/corte_appello_ bo_sent._192_del_14.01.2020_ucraina_integrazione_legami_ familiari_in_italia_umanitaria.pdf.

[74] Italy: Recognition of Humanitarian Protection due to the Deterioration of the Quality of Life in Ukraine. European Database of Asylum Law; 2020. Available from: https://www.asylumlawdatabase.eu/en/content/italy-recognitionhumanitarian-protection-due-deterioration-quality-life-ukraine.

[75] Italy - Administrative Tribunal Declares Decision to Withdraw Reception Provisions Unlawful. European Database of Asylum Law; 2018 Available from: https://www.asylumlawdatabase.eu/en/content/italy$\%$ E2\%80\%93-administrative-tribunal-declares-decision-withdrawreception-provisions-unlawful.

[76] Italy: Recognition of the Right to Enter as Compensation for Illegitimate Collective Expulsions to Libya by the Italian Coast Guard in 2009. European Database of Asylum Law; 2019. Available from: https://www.asylumlawdatabase.eu/en/content/italy-recognitionright-enter-compensation-illegitimate-collective-expulsions-libyaitalian.

[77] Italy-Libya Connection. Human Rights Watch. 2009 Sep 23, Available from: https://www.hrw.org/news/2009/09/23/italy-libyaconnection.

[78] Libya: Renewal of Migration Deal Confirms Italy's Complicity in Torture of Migrants and Refugees. Amnesty International; 2020. Available from: https://www.amnesty.org/en/latest/news/2020/01/libyarenewal-of-migration-deal-confirms-italys-complicity-in-torture-ofmigrants-and-refugees/.

[79] Commissioner Calls on the Italian Government to Suspend the Co-operation Activities in Place with the Libyan Coast Guard that Impact on the Return of Persons Intercepted at Sea to Libya. Council of Europe; 2020. Available from: https://www.coe.int/en/web/commissioner/-/ommissioner-calls-onthe-italian-government-to-suspend-the-co-operation-activities-inplace-with-the-libyan-coast-guard-that-impact-on-the-return-ofp.

[80] Judgement of the CJEU of 21.04.2017 in the case of $X$ and $X v$. Etat belge, C 638/16 PPU, ECLI:EU:C:2017:173.

[81] Migrant Integration not Enough for Stay Permit - Court. ANSA, Latest News; 2019. Available from: https://www.ansa.it/english/ news/2019/11/13/migrant-integration-not-enough-for-stay-permitcourt c7e0d4ae-72cb-496d-a472-bea3bae7c7f3.html.

[82] Humanitarian Protection, EMN Glossary. Available from: https://ec.europa.eu/home-affairs/what-wedo/networks/european migration_network/glossary_search/humanitarian-protection_en.

[83] Positive Premises to Grant the Residence Permit for $\mathrm{Hu}$ manitarian Reasons. Urząd do Spraw Cudzoziemców. 2020; Available from: https://udsc.gov.pl/en/cudzoziemcy/obywatelepanstw-trzecich/zobowiazanie-do-powrotu/przeslanki-negatywnezobowiazania-cudzoziemca-do-powrotu/zgoda-na-pobyt-zewzgledow-humanitarnych/przeslanki-pozytywne-do-udzieleniazgody-na-pobyt-ze-wzgledow-humanitarnych/.

[84] La sentenza di Corte Suprema do Cassazione n. 29460/2019. Associazione per gli Studi Giuridici sull'Immigrazione (ASGI). 2019 Sep 24; Available from: https://www.asgi.it/asilo-eprotezioneinternazionale/cassazione-decreto-sicurezza/.

[85] Corte di Cassazione, ordinanza n. 24388. European Database of Asylum Law. 2019 Sep 30; Available from: https://www.asylumlawdatabase.eu/en/content/italy-courtmust-provide-details-preliminary-assessment-real-risk-presentcountries-origin.

[86] Sentenza di Corte Surema di Cassazione, causa 164/2018. European Database of Asylum Law. 2018 Jan 5; Available from: https://www.asylumlawdatabase.eu/en/content/italy-courtcassation-clarifies-scope-right-legal-aid-\%E2\%80\%9Cirregular- 
migrants\%E2\%80\%9D.

[87] Decision of the ECHR in Case Rackete and Others v. Italy, application no. 32969/19; Available from: https://www.hudoc.echr.coe.int. The Court decides not to indicate an interim measure requiring that the applicants be authorized to disembark in Italy from the ship Sea-Watch 3.

[88] Italy: Preliminary Judge of the Court of Agrigento clears Sea Watch 3 Captain of Charges. European Database of Asylum Law. 2019; Available from: https://www.asylumlawdatabase.eu/en/content/italypreliminary-judge-court-agrigento-clears-sea-watch-3-captaincharges.

[89] Decreto Legislativo 25 luglio 1998, n. 286, Testo unico delle disposizioni concernenti la disciplina dell'immigrazione e norme sulla condizione dello straniero, pubblicato nella Gazzetta Ufficiale n. 191 del 18 agosto 1998 - Supplemento Ordinario n. 139. In accordance with Art. 10(4): "Le disposizioni dei commi 1, 2 e 3 e quelle dell'articolo 4, commi 3 e 6 , non si applicano nei casi previsti dalle disposizioni vigenti che disciplinano l'asilo politico, il riconoscimento dello status di rifugiato, ovvero l'adozione di misure di protezione temporanea per motivi umanitari" (The provisions laid down in paragraphs 1, 2 and 3 and those of Art. 4(3)(6) are not applicable in the situations laid down in the existing regulations, which govern the issues related to political asylum, the granting of refugee status or the adoption of interim measures for humanitarian reasons). Available from: https://www.camera.it/parlam/leggi/deleghe/98286dl.htm.

[90] Regulation (EU) no. 604/2013 of the European Parliament and of the Council of June 26, 2013 Establishing the Criteria and Mechanisms for Determining the Member State Responsible for Examining an Application for International Protection Lodged in one of the Member States by a Third-country National or a Stateless Person. Official Journal of the European Union. 2013;(L 180/31). Available from: https://eur-lex.europa.eu/legal-content/EN/TXT/PDF/ ?uri=CELEX:32013R0604\&from=EN.

[91] Judgement of the Higher Administrative Court of Düsseldorf, 8.05.2018, Case 8L5135/17A. Germany: Administrative Court of Dusseldorf quashes transfer of Syrian family to Romania. 2018; Available from: https://www.asylumlawdatabase.eu/en/content/ germany-administrative-court-dusseldorf-quashes-transfersyrian-family-romania.

[92] Judgement of the European Court of Human Rights of 4.11.2014 r. in the case of Tarakhel v. Switzerland, Complaint no. 29217/12.

[93] Judgement of the Federal Administrative Court of Germany. 2018 Aug 20; Available from: https://www.asylumlawdatabase.eu/ en/content/germany-federal-administrative-court-rejects-bamfappeal-regarding-returns-refugees-bulgaria.

[94] Judgement of the Augsburg Administrative Court. 2018 Nov 2; Available from: https://www.asylumlawdatabase.eu/en/content/germany$\%$ E2\%80\%93-augsburg-administrative-court-rules-case-dublintransfer-pregnant-asylum-seeker.

[95] Judgement of the Administrative Court of Magdeburg. 2018 Nov 13; Available from: https:/www.asylumlawdatabase.eu/en/ content/germany-\%E2\%80\%93-magdeburg-court-suspendsreturn-beneficiary-international-protection-greece.

[96] Judgement of the Administrative Court of Munich. 2019 Aug 8; Available from: https://www.asylumlawdatabase.eu/en/content/germanyadministrative-court-munich-rules-against-provisional-returnsyrian-applicant-greece.

[97] Germany - Regensburg Administrative Court Rules on Absconding and time limits for Dublin Transfers. 2019; Available from: https://www.asylumlawdatabase.eu/en/content/germany$\%$ E2\%80\%93-regensburg-administrative-court-rules-abscondingand-time-limits-dublin-transfers. Moving further, the administrative court of Regensburg in its judgement of 9 January 2019 provided interpretation of Art. 29(2) of the Dublin Regulation III.

[98] Judgement of the Berlin Administrative Court. 2018 Sep 4; Available from: https://www.asylumlawdatabase.eu/en/content/germany$\%$ E2\%80\%93-berlin-administrative-court-rules-possibility-familyreunification-during-minor\%E2\%80\%99s

[99] Judgement of the Munster Administrative Court. 2018 Dec 22; Available from: https://www.asylumlawdatabase.eu/en/content/germany$\%$ E2\%80\%93-m\%C3\%BCnster-administrative-courtobligedgerman-asylum-authorities-accept-delayed-take.

[100] Judgement of the Court of 13.11.2018 in the case of $X$ and $X v$. Staatssecretaris van Veiligheid en Justitie, joined cases $C 47 / 17$ and C 48/17, ECLI:EU:C:2018:900.

[101] Act of 14 June 1960 Code of Administrative Procedure. Journal of Laws. 1960;(30). Available from: http://www.parliament.am/library/ varchakaniravaxaxtum19/lehastan.pdf.

[102] Białas J, Górczyńska M, Witko D. Dostepp do procedury azylowe na zewnętrznych granicach Polski Stan obecny i wyzwania na przyszłość. 2019; Available from: www.hfhr.pl.

[103] Art. 28 of the Act on foreigners concerns the refusal of entry into the territory of the Republic of Poland to a foreigner. In accordance with its paragraph 2(2), a decision refusing entry is not issued with regard to a foreigner, when he/she:

a) declared an intention to submit an application for international protection in cases laid down in Art. 28(1) or Art. 6(1) of the Act of 13 June 2003 on granting protection to foreigners on the territory of the Republic of Poland b) submitted an application for international protection (...).

[104] Judgement of the Supreme Administrative Court, Ref. no. II OSK 345/18. 2018 Sep 20; Available from: http://orzeczenia.nsa.gov.pl/ doc/6422D006AE.

[105] Judgement of the Supreme Administrative Court of 20.09.2020, Ref. no. OSK 445/18. In accordance with the reasoning of the court: "As a rule, the statements of the person submitting a cassation complaint should be given credit, to the effect that such significant activities as questioning or interviewing a foreigner on the border should take place in the presence of his/her legal representative, if such had been appointed. However, the specificity of the proceedings requires assuming that such an obligation exists on the side of the administration only when the legal representative had already been appointed and is present at the moment of crossing the border whereas the appointing of a legal representative does not have to entail the submission of the authorization documents".

[106] Application no. 51246/17, D.A. and Others against Poland lodged on 20 July 2017. European Court of Human Rights; 2017. Available from: http://hudoc.echr.coe.int/eng?i=001-177298.

[107] Application no. 51246/17, D.A. and Others against Poland lodged on 20 July 2017. European Court of Human Rights; 2017. Available from: http://hudoc.echr.coe.int/eng? $\mathrm{i}=001-176484$.

[108] A Visit to the Railway Border Crossing in Terespol. Rzecznik Praw Obywatelskich. 2019; Available from: https://bip.brpo.gov.pl/pl/content/wizytacja-kolejowego-przejsciagranicznego-w-terespolu-wrzesien-2019.

[109] Act of July 15, 1987 on the Ombudsman. Journal of Laws 2020627 of 20200408;See: Art. 13 and the following.

[110] Judgement of the Supreme Administrative Court of 18.12.2019, Ref no. OSK $2219 / 19$

[111] Rzecznik Praw Obywatelskich. Available from: https://www. rpo.gov.pl/pl/content/nsa-uwzglednil-argumenty-rpo-w-sprawienieprzyznania-ochronymiedzynarodowej-obywatelowi-rosji/.

[112] Judgement of the Supreme Administrative Court of 19.09.2019, Ref. no. OSK $1849 / 19$.

[113] Judgement of the European Court of Human Rights of 10 April 2018 in the case of Bistieva and others v. Poland, application no. $75157 / 14$

[114] Helsińska Fundacja Praw Człowieka. Available from: https://www.hfhr.pl/detencja-dzieci-cudzoziemcow-w-polsc.ehfpckieruje-wystapienie-do-specjalnego-sprawozdawcy-onz/. 